\title{
THE PERFORMATIVE IN SECOND LANGUAGE EDUCATION: AN EXAMPLE OF THE COMPLEXITY OF THE DISCIPLINE
}

\begin{abstract}
Second language education (SLE) must remain open to developments in the world if it is to be relevant to those who have an investment in it: learners, teachers and researchers. However, the broadening of the interdisciplinary nature of SLE that may occur because of this is not without its problems. New areas will bring ideas and terminology that will make SLE as a discipline even more complex. In addition, the ideas and terminology may be disputed in the fields from which they originate thus compounding the problem of complexity. The article looks at the example of the performative in SLE and how it supports an approach that is interdisciplinary and intercultural. It also looks at some of the problems this causes: the implications of implementing an SLE practice that is performative, the fact that there are different performative practices, as well as variance between seemingly similar performative practices because of national and cultural differences. The article concludes with the description of two studies which show the complex nature of performative SLE as praxis.
\end{abstract}

Keywords: discipline, complexity, intercultural, interdisciplinary, performative turn, performative SLE

Słowa kluczowe: dyscyplina, złożoność, międzykulturowy, interdyscyplinarny, zwrot performatywny, glottodydaktyka performatywna 


\section{Introduction}

The debate around whether or not second language education (SLE) should be viewed as a discipline in its own right or as a sub-discipline of pedagogy continues. This article does not aim to rehearse the arguments covered more fully in other publications (Wilczyńska, Michońska-Stadnik, 2010; Dakowska, 2014), rather it accepts SLE as a young discipline that (out of necessity) has a complex pedigree and, therefore, terminology. In part, this is because SLE has concerns related to a number of different areas: those specifically connected to SLE and those which shed light on communicative competences. The areas related to SLE include communication sciences, linguistics, sociolinguistic and social psychology. The areas dealing with the development of communicative competences are pedagogy and didactics in general, cognitive linguistics, psycholinguistics and psychology (Wilczyńska, Michońska-Stadnik, 2010: 66-69). This complexity is also due to the fact that SLE must respond to changes that are taking place in the world if it is to remain relevant. This means that SLE practice should be inclusive of new trends in teaching-learning. However, the broadening of the interdisciplinary nature of SLE that may occur because of this is not without its problems. New areas will bring ideas and terminology that will make SLE as a discipline even more complex. In addition, these ideas and terminology may be disputed in the fields from which they originate, thus compounding the problem of complexity.

With regard to the above, one of the recent developments in SLE has been the growing acceptance of an approach that is intercultural (KarpińskaMusiał, 2015; Sobkowiak, 2015) as well as the adoption of a practice that is performative (Crutchfield, Schewe, 2017). In this article, interculturality in SLE is viewed in connection with other related approaches and, following argumentation put forward by Crutchfield and Schewe (2017), it is accepted that such an approach is best served by a practice that is performative. On from this, the implications for the implementation of the performative turn in SLE are considered along with some of the problems this may cause: namely, there are different performative practices which vary because they originate from different traditions but also because they have developed in different countries and cultures. Finally, two studies which show the complex nature of a performative SLE as praxis are considered. One is a project which continues the author's research into the performative turn in his own teaching and concerns learners in higher education at a college in Poland. The other, from the literature, concerns a project in which immigrant refugee children participated in a course of English for speakers of other languages (ESOL) which took place in Scotland. 


\section{The intercultural in SLE}

Crutchfield and Schewe (2017: xi-xii) believe that SLE needs to respond to what is occurring in the world: from their point of view, the migrant crisis that is presently unfolding across Europe and also the rest of the world. In recounting their model of SLE, the authors draw upon ideas of multiculturalism and integration that are supported by the performative turn.

In explaining their choice of the intercultural model as appropriate for the second language classroom, Crutchfield and Schewe (2017: xii-xiii) delineate other models available. First of all, they outline the shortcomings of the monocultural and multicultural approaches, before going on to describe the possibilities of the inter- and transcultural models and the leading role the performative has to play. The monocultural solution, for instance, is viewed to be untenable as it treats certain members of society as second-class citizens, while the multicultural solution, in which different groups live in legally guaranteed respect of each other is also dismissed as unsatisfactory because this is done in lieu of mutual understanding. The intercultural and transcultural models, meanwhile, are perceived as more successful. With regard to these models, the intercultural mode allows for dialogue as well as understanding between different cultures within society while, more recently, a transcultural approach has been proposed, within which "cultures themselves become hybrid, porous, improvisational, subject to recombination and revision" (Crutchfield, Schewe, 2017: xii) and where the individual is placed central to the decisions to be made.

In developing their argument further, Crutchfield and Schewe concentrate on the intercultural approach which, in their view, because it is based on dialogue and emphasizes communication and language, means it is an appropriate model for the foreign language classroom. It also allows understanding to be viewed as a dynamic process which can include misunderstanding: interlocutors are always open to the possibility of not understanding one another, of trying to gain an understanding, and through this, the transformation of self that this entails. Additionally, for the purposes of foreign and second language teaching-learning, the classroom itself is viewed as an important place. This is because it enables spaces within which intercultural exchanges can be rehearsed as well as have an actual impact: teachers and learners are equal beneficiaries of the dialogues that take place there, which have the potential to be mutually transformative (Crutchfield, Schewe, 2017: xiii). 


\section{The performative turn in SLE and the humanities}

Crutchfield and Schewe (2017: xiii) also believe that a didactics which is performative, that engages the person holistically, has a central role to play in the intercultural exchanges that take place in SLE. This is because the transformations that occur are all the stronger when peopleare engaged bodily and emotionally, and not just cognitively (Crutchfield, Schewe, xiii-xiv). Indeed, in order to remain inclusive while garnering the possibilities available to the performative, Crutchfield and Schewe (2017: xiv) attempt a "catch all" definition for it in the field of foreign language education: "any and all pedagogical approaches that make conscious use of performance - embodied action before witnesses - as an essential tool for learning". They also qualify this statement by explaining that they are focusing specifically on foreign and second language teaching-learning "that makes use of techniques, forms and aesthetic process adapted from the performing arts - particularly the theater"(Crutchfield, Schewe, 2017: xiv).

However, in order to gain a fuller picture of what might be proposed with regard to the performative it is worth turning to a more general view. Ewa Domańska (2007), for example, writing about the performative turn in the humanities, believes it creates a situation in which traditional subject-object relations are disrupted or lost to be replaced by bonds of mutual cooperation through action. This is because in a world which is complex and dynamic - prone to dramatic events - understanding mediated through textual analysis and the hierarchies it upholds are no longer adequate. As a result of this, the traditional view of the human being as a lone subject is given up for a situation in which the status of subject is now shared with a range of previously unacknowledged (unacceptable) partners. This means that animals, clones, cyborgs, mutants, terrorists and even inanimate objects are now viewed as being on the same level as the human (Domańska, 2007: 54). For Domańska too, the subject of the performative turn is neither passive nor contemplative, but prone to change and even violent disruptions (revolution). The former homogeneity of the subject has also gone, to be replaced by a strong and hybrid entity which has agency. This is a subject that initiates and acts rather than spectates, interacts and works with other subjects (human and non-human) rather than alone (Domańska, 2007: 56). In this transformation of the subject it also has to be understood that the non-human entities as subjects have not been anthropomorphized and thus given human intentionality, rather it is recognized that there are now subjects with agency who work together but in different ways because, as Andrew Pickering, the American philosopher of science states: "human beings act but non-human entities also act” (Domańska, 2007: 57-58, translation - MB). 
The performative turn Domańska describes, which emphasizes cooperation and partnership with a subject that is dynamic and heterogeneous, has links with the model of the performative that Crutchfield and Schewe (2017: xiii) outline for SLE and the people (subjects) they view to be involved in the teaching-learning process of a second language. In addition, the fact that this "new" subject is born out of the world as it exists rather than being a mediation with that world, also relates to the first point made in section two above, concerning a SLE that is intercultural: it needs to be responsive to what is occurring in the world that surrounds it. The dynamic processes inherent to intercultural exchanges, which involve transformation of Self, are also well served by the performative turn as described by Domańska where there is a dynamic subject that has agency and through contact with the other, is constantly open to (undergoing) change. And, it is important to state here that for Crutchfield and Schewe, as for Domańska, the intercultural contact that occurs thus, is not the absorption of the "newcomer" minority to the established majority, but rather an exchange from which everyone involved benefits (learns) and is able, to a certain degree, to remain autonomous.

Looking at the above, it is clear that a performative SLE is broad and complex in scope and can be concerned with, among others, the following areas:

- ethics - a redefinition of the subject and the form relations with the other might take,

- the social and cultural - SLE is responsive to and based within the wider world that surrounds it,

- critical pedagogy - there are transformative possibilities leading to an empowerment of the subject.

In addition to this, in proposing performative foreign and second language didactics, Crutchfield and Schewe (2017: xiv) are also aware that it is not a fixed paradigm as there is a continuing debate around its key concepts. This, at a very basic level, is evidenced by the range of practices that exist in performance education between countries, each of which has developed its own procedures and terminology.

\section{Differences in performance related education between countries}

The performative turn in education has evolved in different ways in different countries. In the United Kingdom, for instance, there is 'drama in education', which is different to 'theater in education', while in the USA there is 'theater

\footnotetext{
${ }^{1}$ The titles given in lower-case letters refer to approaches in general rather than the names of subjects. The titles given in upper-case letters are recognized subjects.
} 
education', which in turn is different to the school subjects of 'Theater' or 'Drama'. Meanwhile, in Germany there are 'Darstellendes Spiel' ('Representational Play') and 'Theaterpädagodik', which, respectively, equate to the US 'Drama' and 'theater education' - the latter being training for theatre teachers. There is also 'Dramapädagodik', which is a pedagogical approach to subjects similar to the UK's 'drama in education'. One might add that in Poland (the perspective from which I am writing), there is also a diversity in relation to education in general and theatre education. In general education there is, for example, 'Pedagogikadramy' (Drama Pedagogy),similar to 'drama in education' and 'Dramapädagodik', while with regard to theatre related education there is 'PedagogikaTeatru' (Theatre Pedagogy), which might be seen to correspond with 'theater education' and 'Theaterpädagodik'. Generally too, the situation is further complicated by the fact that there are other performative practices, not just those based in theatre or drama, which also have a place in education. And, while Crutchfield and Schewe do not make specific mention of what these practices are, other than they belong to the performing arts, from this author's particular point of interest, performance art (Garoian, 1999), live art (Layzell, 1993), as well as happening (Królica, 2006; Blaszk, 2017), might be cited. It is evident, therefore, that the situation concerning the performative and performance practices in connection with education is complex. ${ }^{2}$ However, it has to be noted that the complexity relating to performative practices across the different cultures (histories and traditions) of various countries, is not unknown to SLE in relation to its own identity. As a discipline, it has to contend with a range of practices and names. Wilczyńska and Michońska-Stadnik (2010: 42-46), for instance, list 16 different practices for the three countries and one language culture they survey. ${ }^{3}$ In which case, as a discipline, it might be said that because it is situated across different countries and language cultures, out of necessity, SLE has a tendency towards the intercultural and interdisciplinary beyond the fact, simply, that in its theory

\footnotetext{
2 This does not aim to be a full account comprising all of the possibilities available in the countries given, rather it shows the possibilities given by Crutchfield and Schewe, as well as those that are known to this author at the present time.

3 The countries and language culture, as well as the practices Wilczyńska and Michońska-Stadnik give are as follows: Poland - dydaktyka języków obcych, glottodydaktyka, metodyka (nauczania JO), językoznawstwo stosowane; France - didactique des langues (vivantès), didactologie des langues-cultures, méthodologie de l'enseignement des langues; English speaking countries - applied linguistics, second language acquisition, foreign language teaching methodology, educational linguistics, foreign language didactics; Germany - zweitspracherwerbsforschung, sprachlehrforschung, fremdsprachendidaktik, fremdsprachenmethodik.
} 
and practice it draws upon the research and findings of other disciplines(see section 1. above). A SLE that is performative, therefore, adds to this existing complexity by offering more possibilities connected to the different types of performance and their related research and practices, as well as the different countries (histories and traditions) they spring from.

Finally, in addition to questioning the possibility of there being only one performative practice within education, Crutchfield and Schewe (2017: xv) also note that 'performance' is a culturally loaded term, with the West having established a particular scientific epistemology in the second half of the twentieth century ${ }^{4}$ which may not necessarily be shared by other nations and cultures. Therefore, when working with different cultures in a classroom situation, teachers and researchers are warned that people may (will) respond to performative practices in different ways, while to avoid cultural imperialism: "we must proceed with extreme caution both in the way we speak of performance in theoretical discussions and in the way we apply it in praxis" (Crutchfield, Schewe, 2017:xv). In connection with this, and in line with a 'performative shift' in education research generally, the focus is now on how education is done rather than solely on what is done, with the emphasis upon the specific processes (both physical and verbal) used in knowledge generation as well as the kind of knowledge that then stems from it (Crutchfield, Schewe, 2017: xvi). This means that analyses of the performative in SLE must take into account its practice with regard to particular encounters.

\section{Performative SLEas praxis}

As well as the complexity of aSLE that is performative with regard to a metaview, when it comes to praxis, the nature of each encounter needs to be taken into account, as each is unique with regard to the situation in which it unfolds as well as the people who are involved. To illustrate what is meant by this, two studies shall now be looked at. The first is part of a research project carried out by this author and involves students from a higher education college in Poland. The second is taken from the literature and describes an ESOL course upon which adolescent immigrant refugees in Scotland participated.

\subsection{Study 1: Performative SLEworkshops for students at a university in Poland}

The workshops that took place, which resulted in a happening, involved students from Państwowa Wyższa Szkola Zawodowa (State University of Applied

${ }^{4}$ Crutchfield and Schewe (2017: xv) view this as largely due to the work of Victor Turner (1957), Erving Goffman (1959) and Clifford Geertz (1973). 
Sciences) in Płock. The workshops and happening are part of a larger cycle of research carried out by the author. In previous research, the implementation of a course of extra-curricular English teaching in a school, based upon the principles of happening, was studied (Blaszk, 2016; Blaszk, 2017). In this project, the research focused upon how those principles might be implemented in a higher education institution and what areas of the teaching-learning process the students viewed to be significant. As the aim of this section of the article is to describe a practical application of a performative SLE, with a view to show the number of areas it crosses over and therefore its complexity, the author shall restrict himself to brief descriptions of the project set-up, what occurred and some of the data collected and its interpretation.

The workshops in preparation for the happening took place for four teaching hours each day between Monday the $15^{\text {th }}$ October and Friday $20^{\text {th }}$ October 2018. In total, 18 students were involved in the workshops, with 15 people eventually participating in the happening. The workshops were run in English, a language all of the students were studying as an $L 2$ at the college. The students' proficiency in $\mathrm{L} 2$ varied - between $\mathrm{B} 2$ and $\mathrm{C}^{5}$ - as did their experience of using it: there were students from the first level of studies (BA) as well as those from second level studies (MA). The emphasis with regard to $L 2$ was production, especially in relation to speaking. In line with precepts underlying happening, the workshops were planned to have a high performative content i.e., a range of involvements other than simply the cognitive from all of the students in all of the activities.

In connection with this, to plan and prepare for the happening, three forms of activity were engaged in by the participants. The first was an individual exploration of three texts written by the Polish author Stefan Themerson: the novels Bayamus (1945) and Cardinal Pölätüo (1954), as well as the play Kość $w$ gardle (1953). Before the workshops began, ${ }^{6}$ the participants were asked to read the texts and react to them by noting down words and phrases which they (the participants) found significant. They were also requested to create images or movements as part of these reactions. For the second form

\footnotetext{
5 This is according to levels given in the Common European Framework of Reference for Languages (Council of Europe, 2001). No tests were carried out to assess the students' language levels before the workshops. This range is based upon my contact with the students in relation to their productive skills - speaking and writing. It is also based upon knowledge that students studying modern languages in higher education institutions in Poland start with and/or attain these levels.

${ }^{6}$ The texts were sent approximately one month in advance of the workshops. The novels were written in English and the play in Polish. This meant that during the discussions in the brainstorm, some of the ideas the students presented had to be translated into English.
} 
of activity, participants worked together in various and differently sized groups to discuss, plan and prepare the happening. For example, in a brainstorm during the workshops, the participants were asked to share and discuss the ideas they had worked on individually in relation to the Themerson texts. This was followed by the joint production of posters which became the basis for enactments: physical and verbal representations of ideas given on the posters. The third form of activity to occur during the workshops, physical involvement, was intertwined with the second, so that it ran simultaneously with the work on planning and preparing the happening. The physical activities used included those taken from published sources and theatre workshops: e.g., Becoming a picture (Maley, Duff, 1987: 129130), a game of tag with chairs (Rintoul 2011).

The happening - Themerson happening - was enacted in Płock ${ }^{7}$ town square on Friday $20^{\text {th }}$ October 2018. It was based on the reactions to the Themerson texts and the work done throughout the workshops. During the happening, the students carried out various actions using Polish: an announcement to start the happening, a woman reciting Mickiewicz's Pan Tadeusz, a man in a bear suit attacked whenever he tried to rest, men and women asking complete strangers for a hug, a man engaged in a vigorous argument with his imaginary mother, a coffin scene accompanied by prayers and a final action in which a pack of wolves savage a cloth before running off with posters advertising the happening.

Throughout the workshops, the participants were encouraged to work together in English, to put forward their own ideas in reaction to the Themerson texts and to find different ways to express those ideas: verbal, physical, visual and sound. In addition, during the workshops, the emphasis was on the exploration of the participants' own ideas towards the creation of a happening, rather than the accommodation of the participants' ideas to a readymade format for a happening. This meant that in the final happening there were, as described above, some surprising juxtapositions: the recitation of Mickiewicz's Pan Tadeusz and the participant in a bear suit stalking around Płock town square, some of the participants offering hugs to strangers and another participant arguing with his imagined and therefore, invisible, mother.

The involvement of the participants during the workshops, as well as the happening, display characteristics that can be attributed to happening. According to the characteristics for happening outlined by Blaszk (2017: 5456), and taken from various sources (Pawłowski, 1982; Kirby, 1966; Morawski, 1971; Schechner, 1982; Garoian, 1999), these included:

- concentration on active participation and not just a final product (process),

\footnotetext{
${ }^{7} \mathrm{~A}$ large town in the centre of Poland, close to the capital city, Warsaw.
} 
- promotion of equality between participants (participation and indeterminacy),

- encouragement of different points of view (multicentrism),

- use of a broad range of materials and ways to express ideas (abolition of borders between forms, interdisciplinarity and indeterminacy),

- physical engagement in the learning process (body intelligence),

- engagement in activities without always knowing where they may lead - open ended activities rather than closed (chance, paradox and dream logic),

- personal perspective upon and assessment of what is done (reflexivity). It was also a happening in which aesthetic concerns were to the fore rather than critical (socio-political) ones (Blaszk, 2017: 57-58). In addition, symbol systems other than language were used - there was high visual content along with the use of sound and music.

The characteristics of happening that were promoted during the workshops showed themselves in the happening. To outline only a number of them: there was body intelligence displayed in the physical nature of the enactment as a whole, dream logic in the disconnected nature of the actions that were presented, and multicentrism in that each of the actions were derived from individual interpretations of the Themerson texts read by the students. A fuller picture of what occurred is also given by the written responses to the workshops and happening given by the students in emails sent to the author. These show concerns already mentioned in relation to an intercultural performative SLE overall: the ethical, the social and cultural, and the critical (section 3).

In connection with the ethical, for example, Roksana (13 November 2018) ${ }^{8}$ recounts how she "met many new people and with those I had already known, I tightened the bond", while Agata (7 November 2018) described how by the end of the workshops she had gained a feeling of strength which came from working with other people in the group and which meant that during the happening contact with strangers on the street was not a problem. In terms of the social and cultural, Hania (28 October 2018) described how the workshops and happening helped her "to understand and appreciate Themerson's stories. It caused lots of interesting discussions between me and my friends". Mateusz (4 November 2018) also mentioned how the creativity, play and performance used throughout the workshops and happening improved the students' skills with regard to cooperation. Meanwhile, in relation to a critical

\footnotetext{
${ }^{8}$ The names given have not been changed. The names as well as the comments presented here are used with the consent of the students who took part in the workshops and happening. The dates given refer to when the emails were sent to the author.
} 
stance, Adrian (4 November 2018) admitted that: "It still is fascinating to think and try to analyze the methods and the thought processes that we had implemented during our workshops", so that his account of what occurred throughout the workshops and happening concerned the activities of the people in the group as well as those (mostly homeless people) he met during the happening.

It is noticeable too that the students who wrote responses to what had taken place in the workshops and happening, mention the fact that involvement in both helped them with regard to affective factors that were part of the teaching-learning process. Roksana (13 November 2018), for example, wrote about overcoming "a blockade deep inside of me", Hania (28 October 2018) about overcoming "some of my difficulties [shyness is mentioned earlier in the email]", and Agata (7 November 2018), the personal growth that took place through negotiation of a space outside of her comfort zone.

\subsection{Study 2: An ESOL course for immigrant refugee children in Scotland}

Frimberger's (2017: 24) work with immigrant refugee children in Scotland is another example of the complexity of a performative language learning encounter on the practical level. The specific situation Frimberger recounts relates to an identity text ${ }^{9}$ created by two learners, Nam $\mathrm{Ha}$ and Yun, which was then performed as part of a drama workshop. The text, quoted in full by Frimberger (2017: 21-22) reads as follows:

This is an egg - a baby animal - it hatches into a good world, from darkness to light, with small black eyes and little feet. Its heart is beating fast - everything is new and scary. He wants to find somewhere safe. So he goes to Scotland. Everything is different. It's very hard to find love. He finds peace and freedom. He sees wonderful things - they are soft and lovely colours. He feels relaxed and comfortable. He feels hope for the future. A rainbow! He finds love, friendship, someone to hold hands, someone to help, to be together, to look after each other. To make a beautiful sound together. Together they are happy, they laugh and play like family. They are full, altogether complete. (Nam Ha and Yun)

The ESOL course upon which Nam Ha and Yun participated, and Frimbereger was involved, was based in a Glasgow college and catered for 16 to 20 year old adolescents from different cultures across a broad range of languages. ${ }^{10}$

\footnotetext{
${ }^{9}$ A text created by learners which can explicitly or implicitly symbolize political, social or economic issues critical to their lives.

${ }^{10}$ These included "Kinda, Arabic, Farsi, Vietnamese, Mandarin, Dutch, French, Pushto, Borgow, Tigrinya and Amharic" (Frimberger, 2017: 24).
} 
The participants also had different levels of English which was either L2, L3 or L4. All the learners, like Nam Ha and Yun, each had their own particular histories including war, political conflict and/or escape from repressive regimes, as well as loss of parents and relatives. The course also recognized and allowed the learners to explore the emotional, practical and intellectual skills they had gained in their short lives. In addition, as Frimberger (2017:25) states, the word 'refugee' is itself a term which covers a broad range of positions: legal, socioeconomic, personal, psychological and spiritual, all of which were taken into consideration when dealing with the individuals who were grouped together under the one label. As a result of this, the $16+$ programme, as it was called, not only covered the learners' language needs but also dealt with their psychological requirements, the individual skills they had acquired and their status(es) as refugees. To do so, the ESOL curriculum included a diverse mix of 'pedagogies'11 including: "creative arts pedagogies, outdoor learning programmes, extensive personal guidance [...] counselling and mental health [...] [provision]" (Frimberger, 2017: 24).

In connection with how to work in an educational space which is so complex, where the learners' lived experiences were so diverse, a critical intercultural language pedagogy was used. This was felt to be especially important as it meant learners were active in setting the agenda and could also educate others by sharing their life experiences. It also allowed for an educational space in which difference and conflict were actively engaged with rather than denied, allowing "wider realities of social contestation that affect students' lives to become visible" (Frimberger, 2017: 27). As a result of this, the educational space for this performative language practice was one in which reflection was enabled and where learners could become aware of how the forces that affect their lives are maintained or can be transgressed.

Overall, therefore, Frimberger, her colleagues and the learners were engaged in a performative language learning process which included much more than is suggested by those terms alone. Indeed, the areas that Frimberger (2017: 24) mentions include:

- language needs - level of English, English as a second, third or fourth language,

- psychological requirements - personal experience of war, political conflict, repressive regimes, loss of parents and relatives,

- recognition of individual skills - emotional, practical and intellectual,

- positions of refugee status - legal, socioeconomic, personal, psychological and spiritual.

\footnotetext{
${ }^{11}$ Frimberger uses the term 'pedagogies' for these specializations and I continue this practice here.
} 
In addition, the 'pedagogies' used, included:

- creative arts pedagogies,

- outdoor learning programmes,

- counselling and mental health provision

Importantly too, a critical pedagogy was used which allowed for the use of the learners' own experiences and reflection upon the processes they were involved with and how they might deal with them (Frimberger, 2017: 25-30).

\section{Conclusion}

In the article a performative SLE that is intercultural has been outlined with the purpose of showing its complexity in connection with the number of different areas it connects to as well as the different countries and language cultures it crosses. I have also suggested that a SLE that is to remain open and responsive to the world and the changes that are taking place needs to be inclusive and, because of this, interdisciplinary. Additionally, in line with other authors who call for a systematic approach to the practice and research into SLE (Wilczyńska, Michońska-Stadnik, 2010; Dakowska, 2014), this also means that SLE as a discipline needs to be aware of the sources in its practice as well as signal those sources in the way practitioners and researchers write about it.

In the two studies described, it is evident that the practical application of a performative SLE that is responsive to its surroundings and the people (learners and teachers) who participate in it is, out of necessity, unique. Each case, therefore, may relate to the various areas that are already the domain of SLE, but also, other, previously unforeseen considerations and areas may be included. In the first study described, there are, for example, areas relating to the performative, such as the ethical, the social and cultural, as well as the critical. In particular, the influence of a performance strategy relating to happening was evident. In the second study, the areas of outdoor learning and the creative arts were incorporated. Moreover, and perhaps more importantly, the refugee status of the migrants and the provision of mental health care were also areas that had to be considered.

Finally, in connection with the complexity of SLE as a discipline overall, and the imperative that it should be inclusive, the situation does not appear to have changed since Bańczerowski (1975: 24) wrote about one of its Polish equivalents, glottodidactics, almost half a century ago:

The aims of teaching are heterogeneous and it seems that at the present stage of glottodidactic science they cannot be accounted for in any homogeneous 
theory which would guarantee the optimal achievement in teaching such different skills as comprehension, speaking, reading, writing, and translating. Consequently the attainment of these heterogeneous skills presupposes a choice and combination of different theories, or at least some aspects of them. In this way, we arrive at the notion of an eclectic or selective glottodidactic theory which is based on the evaluation of various complementary theories.

And, while Bańczerowski (1975: 21-22) may have been concerned specifically with the different theories available to SLE at the time he was writing, in today's world where interdisciplinary approaches are seen to be advantages, the promotion of a SLE theory that is inclusive of areas other than those traditionally accepted but necessary to its practice, would appear to make sense.

\section{REFERENCES}

Bańczerowski J. (1975), Is Metaglottodidactics Necessary? (in) "Glottodidactica", No. 8, pp. 21-26.

Blaszk M. (2016), An inquiry into happening in school education: some of the questions it poses to teaching English as a foreign language in schools (in) Stanulewicz D., Janczukowicz K., Rocławska-Daniluk M. (eds.), Language education: controversies, observations and proposals. Frankfurt am Main: Peter Lang, pp. 199-214.

Blaszk M. (2017), Happening in Education - Theoretical Issues. Frankfurt am Main: Peter Lang.

Council of Europe (2001), Common European Framework of Reference for Languages: Learning, teaching, assessment. Cambridge: Cambridge University Press.

Crutchfield J., Schewe M. (2017), Introduction: Going Performative in Intercultural Education. International Contexts, Theoretical Perspectives and Models of Practice (in) Crutchfield J., Schewe M. (eds.), Going Performative in Intercultural Education. International Contexts, Theoretical Perspectives and Models of Practice.Bristol: Multilingual Matters, pp. xi-xxv. Dakowska M. (2014), O rozwoju dydaktyki języków obcych jako dyscypliny naukowej. Warszawa: Wydawnictwo Uniwersytetu Warszawskiego.

Domańska E. (2007), „Zwrot performatywny” we współczesnej humanistyce (in) "Teksty Drugie", No. 5, pp. 48-61.

Geertz C. (1973), The Interpretation of Cultures. New York: Basic Books. Goffman E. (1959), The Presentation of Self in Everyday Life. New York: Anchor Books. Frimberger K. (2017), The Ethics of Performative Approaches in Intercultural Education (in) Crutchfield J., Schewe M. (eds.), Going Performative in 
Intercultural Education. International Contexts, Theoretical Perspectives and Models of Practice. Bristol: Multilingual Matters, pp.21-40.

Garoian C.R. (1999), Performing Pedagogy: Toward an Art of Politics. Albany: State University of New York Press.

Karpińska-Musiał B. (2015), Międzykulturowość w glottodydaktyce. Gdańsk: Wydawnictwo Uniwersytetu Gdańskiego.

Kirby M. (1966), Happenings: An Illustrated Anthology. New York: E.P. Dutton $\&$ Co., Inc.

Królica, M. (2006), Drama i happening w edukacji przedszkolnej. Kraków: Oficyna Wydawnicza Impuls.

Layzell R. (1993), Live Art In Schools. London: The Arts Council of Great Britain. Maley A., Duff A. (1987), Drama Techniques in Language Learning: A Resource Book of Communication Activities for Language Teachers. Cambridge: Cambridge University Press.

Morawski S. (1971), Happening (2). Rodowód - charakter - funkcje (in) "Dialog", No. 10, pp. 117-144.

Pawłowski T. (1982), Happening. Warszawa: Wiedza Powszechna.

Rintoul D. (2011), Drama workshops attended by the author. Between Festival, 19-21 May. Sopot, TeatrWybrzeże - ScenaKameralna.

Schechner R. (1982), The End of Humanism: Writings on Performance. New York: Performing Arts Journal Publications.

Sobkowiak P. (2015), Interkulturowość w edukacji językowej. Pożnan: Wydawnictwo Naukowe UAM.

Turner V. (1957), Schism and Continuity in African Society: A Study of Ndembu Village Life. Manchester: Manchester University Press.

Wilczyńska W., Michońska-Stadnik A. (2010), Metodologia badań w glottodydaktyce. Wprowadzenie. Kraków: Avalon. 